\title{
CHEMICAL COMPOSITION OF SEEDS AND SEED OIL OF Afraegle paniculata (Rutaceae)
}

\author{
O. Babatunde ${ }^{1}$ G. Ajayi ${ }^{2}$, O. O. Ajayi ${ }^{3}$ I. A. Ajayi ${ }^{2} *$ \\ ${ }^{1}$ Chemical Sciences Department, Faculty of Natural Sciences, Ajayi Crowther University, Oyo, Nigeria \\ ${ }^{2}$ Industrial Unit, Chemistry Department, Faculty of Science, University of Ibadan, Ibadan, Nigeria \\ ${ }^{3}$ Microbiology Department, Faculty of Science, University of Ibadan, Ibadan, Nigeria \\ *Correspondent Author: frajayi@yahoo.com +2348075041170 \\ Received 15 March 2021; accepted 29 March 2021, published online 10 April 2021
}

\begin{abstract}
Afraegle paniculata (Schumach. \& Thonn.) Engl. commonly known as Nigerian powder-flask is a plant of rutaceae family found in West Africa from Senegal to Nigeria. The chemical composition of seeds and seed oil of Afraegle paniculata were evaluated in this study. The seed oil was obtained by soxhlet extraction using $\mathrm{n}$-hexane. Chemical composition analyses involved proximate, mineral element, physicochemical and phytochemical. The percentage mean value of the proximate analysis revealed that the seeds contained $28.81 \pm 0.02 \%$ crude fat, $25.03 \pm 0.12 \%$ crude protein, $10.90 \pm 0.03 \%$ moisture, $3.11 \pm 0.01 \%$ ash, $25.19 \pm 0.02 \%$ crude fibre and $6.96 \pm 0.14 \%$ carbohydrate. The mineral element analysis result showed that potassium $(114.87 \mathrm{mg} / \mathrm{l})$ was the predominant mineral element followed by magnesium $(47.20 \pm 0.037 \mathrm{mg} / \mathrm{l})$ and sodium $(45.37 \pm 0.53 \mathrm{mg} / \mathrm{l})$. Other minerals present were calcium $(2.12 \pm 0.014 \mathrm{mg} / \mathrm{l})$, iron $(1.12 \pm 0.028 \mathrm{mg} / \mathrm{l})$, copper $(0.41 \pm 0.002 \mathrm{mg} / \mathrm{l})$, zinc $(0.39 \pm 0.094$ $\mathrm{mg} / \mathrm{l})$ and manganese $(0.29 \pm 0.005 \mathrm{mg} / \mathrm{l})$. The oil was liquid at room temperature and golden yellow in appearance. The recorded $\mathrm{pH}$, acid, peroxide, iodine, saponification, ester and oil yield values were $3.94,1.29 \mathrm{mgKOH} / \mathrm{g}, 17.57 \mathrm{meq} / \mathrm{kg}, 42.24 \mathrm{mgI}_{2} / 100 \mathrm{~g}, 203.76 \mathrm{mgKOH} / \mathrm{g}, 202.47 \mathrm{mgKOH} / \mathrm{g}, 40.77$ $\% \mathrm{w} / \mathrm{w}$ respectively. The presence of alkaloids, saponins, terpenoids, steroids and anthraquinone were evident in the phytochemical screening of the seed oil. Nutritional profile of A. paniculata seed could offer a scientific basis for use of the seeds and oils both in human diet and some commercial products. Keywords: Afraegle paniculata, proximate, mineral elements, physicochemical and phytochemical.
\end{abstract}

\section{INTRODUCTION}

Recent studies have revealed that some seed oils could find their usefulness as raw materials in formulation of paints depending on the quantity and nature of oil derived from them, as well as animal feeds. [1]. Dietary fats and oils are lipids derived from plants. Although several plant parts may yield oil, commercially, oils are extracted primarily from seeds. Seeds have calorific and nutritive values thereby, contributing to their significance in diets. They are also good sources of edible oils [2]. These oils are increasingly becoming important and various analyses have been carried out primarily because of extensive demands for oils both for human consumption and for industrial applications. The characteristics of oils from different sources depend mainly on their compositions and no oil from a single source can be suitable for all purposes [3]. Lipids derived from plants are widely known to affect serum cholesterol homeostasis and play a crucial role in the development or prevention orange $(6-8 \mathrm{~cm}$ in diameter at the mature age). A. paniculata almonds of the Côte d'Ivoire species have relatively high fat matter (38.4 of development of cancer, atherosclerosis and heart disease, which are the main causes of death in developed countries [4]. There is a bond between the concentration of lipids and the tendency of developing coronary heart disease (CHD), specifically, resulting in blood cholesterol [5]. Human and animals studies have shown that dietary saturated fatty acid increases low density lipoprotein cholesterol (LDLC) concentration and plasma total cholesterol (TC), whereas, they are lowered by polyunsaturated fatty acids [6]. Therefore, there have been great interests in determining the health benefits of vegetable oils (high in mono- and polyunsaturated fatty acids) in relation to risk factors for cardiovascular disease (CVD) [7]. Afraegle paniculata (Schum and Thonn) Engl. belongs to Rutaceae family and commonly found in West Africa. A. paniculata is a shaft 8 to $15 \mathrm{~m}$ tall, with a trunk diameter between 25 and $40 \mathrm{~cm}$. Its alternating leaves (leaflets 3 ) are 8 to $16 \mathrm{~cm}$ long. Its fruits are globular or ovoid, like a big $\%$ ), which makes it useful in oil mill [8]. It is cultivated in the villages for its multiple uses; nutritional, medicinal etc. It is used as a 
traditional medicine in the treatment of malaria in Ghana [9] and also for hypertension and infertility [10]. However, the nutritional value of Afraegle paniculata seed oil of Nigeria species has not been reported. Therefore, this study aimed at determining the nutritional values of Afraegle paniculata seed and seed oil.

\section{MATERIALS AND METHODS Sample Collection and Identification}

Afraegle paniculata fruits were collected from Ajayi Crowther University campus, Oyo, Oyo State, Nigeria. The fruit was identified and authenticated at Forestry Research Institute of Nigeria, Herbarium (111394FHI).

\section{Extraction of seed oil}

A known quantity of the ground seed was packed into a large filter paper and placed into the thimble. The seed kernel oil was extracted using soxhlet extraction method [11] with nhexane (b.p $68^{\circ} \mathrm{C}$ ) as refluxing solvent for $8 \mathrm{~h}$. At the completion of the extraction process, the oil was recovered from the mixture by distillation and stored prior to analysis.

\section{Proximate Analysis}

Moisture content was determined by drying the powdered seed kernel to constant weight at $105^{\circ} \mathrm{C}$. Ash content was evaluated according to the procedure of Otitologbon et al. [12]. Crude protein $(\mathrm{N} \times 6.25)$, crude fiber and crude fat analysis were as described in literature [13] and carbohydrate calculated by difference: [100- (moisture + ash + crude fat + crude fibre + crude protein)] as outlined in literature [14].

\section{Mineral Element Analysis}

One gram of the sample was digested and then subjected to elemental analysis following Umran procedure [15]. Potassium and sodium were evaluated using Jenway PFP7 Flame Photometer while calcium, magnesium, zinc, copper, iron, and manganese were estimated using PerkinElmer A Analyst 200 Atomic Absorption Spectrophotometer.

Qualitative and Quantitative Phytochemical Screenings

Phytochemical screenings (qualitative and quantitative) were carried out on the sample using standard procedures described by Sofowora [16], Solomon et al. [17] Ayoola et al. [18], Obdoni [19] and Indumathi [20].

\section{Physicochemical analysis}

Physicochemical analyses for acid value (free fatty acid), saponification value, iodine value, ester value and specific gravity were in accordance to standard method [21] and Saad [22].

\section{RESULTS AND DISCUSSION \\ Physical characterization of $A$. paniculata fruit}

Presented on Table 1 is the result of the physical properties of A. paniculata fruit. The shape of the fruit is globose with a hard epicarp. The fruit which has brownish mesocarp and 6-8 segments embedded with numerous white seeds immersed in sticky mucilage was observed to be greenishyellowish. The average weight, width and length obtained for randomly selected 30 fruits were $259.81 \mathrm{~g}, 27.51 \mathrm{~cm}$ and $26.48 \mathrm{~cm}$ respectively. The weight of 100 seeds was $24.57 \mathrm{~g}$.

Proximate composition of $A$. paniculata seeds

Proximate analysis result revealed that $A$. paniculata seeds are rich in nutrients especially crude fat $28.81 \pm 0.02 \%$, crude protein $25.03 \pm 0.12 \%$ and crude fibre 25.19 $\pm 0.02 \%$. The moisture content of any food is an index of its water activity and it is a measure of stability and susceptibility to microbial contamination [23]. The moisture content of A. paniculata seeds $10.90 \pm 0.03 \%$ was lower than $53.75 \pm 2.02 \%$ reported by Lakht-e-Zehra et al. [24] for Aegle marmelos (Rutaceae) seeds. Moisture content depends on the environmental conditions such as humidity, temperature and climate and also storage condition. The ash content $3.11 \pm 0.01$ $\%$ was similar to the value reported for $A$. marmelos seed $(3.0 \pm 0.12 \%)$ [25]. It is higher than $1.56 \pm 0.07$ noted in literature for Karachi region grown species of the same A. marmelos L. [24]. Ash content is a reflection that the seeds are rich in mineral elements. Crude fibre which is above $12 \%$ implies high level of undigested cellulose [26]. The crude fibre of A. paniculata seeds $25.19 \pm 0.02 \%$ was much higher than $1.01 \pm 0.10 \%$ of $A$. marmelos $\mathrm{L}$. [24]. High amount of fibre in diet is necessary for elimination of wastes; it can be used to lower serum cholesterol and the risk of coronary heart disease, constipation, hypertension, diabetes, colon and breast cancer [27] The protein content $25.03 \pm 0.12 \%$ was 
quite higher than the range $15-22 \%$ reported for some conventional oil seeds (Adenopus breviflorus and Cumeropsis edilis) and Aegle marmelos seeds [24, 25, 28]. High protein content of the seeds suggests its use in the management of protein deficiency; the high crude fat $28.81 \pm 0.02 \%$ which is similar to that of soy bean $(28.2 \%)$ as noted by Ogbemudia [29] is an indication that the seeds could be a good source of oil. The carbohydrate content $6.90 \pm 0.14 \%$ is lower than $18.88 \pm 0.80 \%$ of $A$. marmelos seeds [24].

Mineral element composition of $A$. paniculata seeds

The result presented on Table 3 showed that the seeds of A. paniculata have high level of potassium (114.87 $\mathrm{mg} / \mathrm{L})$, magnesium $(47.20 \pm 0.037 \mathrm{mg} / \mathrm{L})$ and sodium $(45.37 \pm 0.53$ $\mathrm{mg} / \mathrm{L})$. The high level of potassium in $A$. paniculata seeds was in agreement with the report of Bamba [30] of the Cote d'Iviore species. Potassium is an essential nutrient with an important role in the synthesis of protein and amino acids. Magnesium plays important role in carbohydrate metabolism, nuclei acid and photosynthesis and also as binding agents of cell walls [31]. It also helps in regulating the acid alkaline equilibrium in the body. It has been reported that high magnesium level in drinking water helps in resisting heart disease [32]. Sodium is a major cation in extracellular fluid, which helps in regulation of acid-base equilibrium, maintenance of osmotic pressure in the body and protection against dehydration [33]. The addition of $A$. paniculata seed oil in diet could help to prevent dietary deficiency of potassium, magnesium and sodium due to the fact that the seeds are rich in these three elements aforementioned. The seeds also contain calcium, iron, copper, manganese and zinc in minute quantity.

Table 1: Physical characterization of Afraegle paniculata fruit

\begin{tabular}{ll}
\hline Parameter & Mean \\
\hline Fruit length $(\mathrm{cm})$ & 26.48 \\
Fruit width $(\mathrm{cm})$ & 27.51 \\
Fruit weight $(\mathrm{g})$ & 259.81 \\
Seed weight $(\mathrm{g} / 100$ seeds) & 24.57 \\
Colour of seed & White \\
Colour of fruit & Green/yellow \\
Shape of fruit & Globose \\
Fruit epicarp & Hard \\
Colour of mesocarp & Brown \\
\hline
\end{tabular}

Table 2: Proximate composition \% of Afraegle paniculata seeds

\begin{tabular}{lr}
\hline Parameters & Mean \pm SD \\
\hline Crude fat & $28.81 \pm 0.02$ \\
Crude protein $(\mathrm{N} \times 6.25)$ & $25.03 \pm 0.12$ \\
Moisture content & $10.90 \pm 0.03$ \\
Ash content & $3.11 \pm 0.01$ \\
Crude fibre & $25.19 \pm 0.02$ \\
Carbohydrate & $6.96 \pm 0.14$ \\
\hline
\end{tabular}

Table 3: Mineral element composition of Afraegle paniculata seeds (mg/L)

\begin{tabular}{lc}
\hline Metal & Mean \pm SD \\
\hline Iron & $1.12 \pm 0.028$ \\
Copper & $0.41 \pm 0.002$ \\
Magnesium & $47.20 \pm 0.037$ \\
Calcium & $2.12 \pm 0.014$ \\
Manganese & $0.29 \pm 0.005$ \\
Zinc & $0.39 \pm 0.094$ \\
Sodium & $45.37 \pm 0.53$ \\
Potassium & 114.87
\end{tabular}


Table 4: Physicochemical properties of A. paniculata seed oil

\begin{tabular}{llc}
\hline Parameters & Value & (Bamba et al., 2015) $[\mathbf{8}]$ \\
\hline Acid value $(\mathrm{mgKOH} / \mathrm{g}$ oil) & 1.29 & $2.08 \pm 0.91$ \\
Peroxide value $\left(\mathrm{meqO}_{2} / \mathrm{kg}\right.$ oil) & 17.57 & $3.43 \pm 0.19$ \\
Iodine value $\left(\mathrm{mgI}_{2} / 100 \mathrm{~g}\right.$ oil) & 42.24 & $105.75 \pm 2.11$ \\
Saponification value $(\mathrm{mgKOH} / \mathrm{g}$ oil) & 203.76 & $200.55 \pm 1.40$ \\
Ester value $(\mathrm{mgKOH} / \mathrm{g}$ oil) & 202.47 & $197.75 \pm 1.40$ \\
Oil yield $(\% \mathrm{wt} / \mathrm{wt})$ & 40.77 & $38.40 \pm 0.5 \%$ \\
State at room temperature & Liquid & Liquid \\
Colour & Golden yellow & Yellow gold \\
pH & 3.94 & - \\
Specific gravity & $0.878 \mathrm{~g} / \mathrm{cm}$ & $0.8844 \pm 0.0001$ \\
\hline
\end{tabular}

Table 5: Qualitative phytochemical screening of A. paniculata seed oil

\begin{tabular}{lc}
\hline Test & Oil sample \\
\hline Saponins & + \\
Tannins & - \\
Flavonoid & - \\
Cardiac glycosides & - \\
Anthraquinones & ++ \\
Terpenoids & + \\
Steroid & + \\
Alkaloid & + \\
Phenol & - \\
\hline
\end{tabular}

Key: (+) present; (-) absent

Table 6: Quantitative phytochemical screening of A. paniculata seed oil

\begin{tabular}{llll}
\hline Test & Oil sample(g) & Average yield(g) & \% Yield \\
\hline Alkaloid & 2.0 & 0.003 & 0.15 \\
Saponins & 1.0 & 0.062 & 6.25 \\
Terpenoid & 1.0 & 0.061 & 6.10 \\
\hline
\end{tabular}

\section{Physicochemical properties of $A$. paniculata seed oil}

A. paniculata seed oil was golden yellow in colour and liquid at room temperature (Table $4)$; this is in agreement with the observation for the oil of the Cote d'Ivoire species [8]. The percentage oil yield $40.77 \%$ was closely similar to $38.4 \%$ reported for its counterpart from Cote d'Ivoire. It is however higher than those of some conventional oil seeds: soybean (17.0-21.0\%) and cotton (15.0-24.0\%) [34]. A. paniculata seed is a rich source of oil and could be classified as oil rich seed. The acid value $1.29 \mathrm{mgKOH} / \mathrm{g}$ oil of $A$. paniculata was slightly lower than that of Cote d'Ivoire species; $2.08 \mathrm{mgKOH} / \mathrm{g}$ oil [8]. The value is much lower than the maximum acceptable level for acid value; $4 \mathrm{mgKOH} / \mathrm{g}$ [35]. The low acid value corresponds to a low free fatty acid content, which simply means that the oil has nutritional significance. Peroxide value of A. paniculata seed oil ( $\left.17.57 \mathrm{meq} \mathrm{O}_{2} / \mathrm{kg}\right)$ was higher than the standard range of $2-10 \mathrm{meq} / \mathrm{kg}$ given in literature for fresh oil [35]. Likewise, the value was not in agreement with that of Cote d'Ivoire species: $3.43 \mathrm{meq} / \mathrm{kg}$ [8]; the oil seemed unstable to oxidative degradation. Iodine value is a measure of the degree of unsaturated organic compound, which indicates the reactivity of the double bond. It determines the stability of oils to oxidation and allows the overall unsaturation of the fat to be determined qualitatively. Iodine value of $A$. paniculata seed oil $\left(42.24 \mathrm{mgI}_{2} / 100 \mathrm{~g}\right.$ oil $)$ did not fall within the range of FAO/WHO standard (80-106 $\mathrm{mgI}_{2} / 100 \mathrm{~g}$ oil). The 
saponification value of oil serves as an important parameter in determining the suitability of the oil for soap making. Saponification value of $A$. paniculata seed oil $203.76 \mathrm{mgKOH} / \mathrm{g}$ oil signifies a low molecular weight fatty acid; the oil might find application in soap making industry.

\section{Phytochemical screening of $A$. paniculata seed oil}

Qualitative and quantitative phytochemical analysis which plays a significant role in the study of medicinal properties plants for the confirmation of secondary metabolites was carried out on the seed oil of $A$. paniculata. The presence of various phytoconstituents like saponins, anthraquinone, terpenoids, steroids, and alkaloids was noticed whereas there was none for tannins, cardiac glycosides and phenol (Table 5). Saponins are known for their formation of stable foam in aqueous solution, antimicrobial activity inhibitory property against mould and plant's defence system [36]. Other characteristics of saponins are haemolytic activity, cholesterol binding properties [37] and bitterness [38]. The percentage of saponins in A. paniculata seed oil was highest $(6.25 \%)$ followed by terpenoids $(6.10 \%)$ whereas alkaloids were present in only minute quantity (Table 6). The presence of saponins suggest its usefulness in soap making and therapeutically for anticancer and hypolipidemic activity. Alkaloids have been a prominent class of defence compounds among the secondary metabolites [39]. Their presence in the seed oil of $A$. paniculata suggests its application in pharmaceuticals as well as anaesthetics, narcotics, analgesics and central nervous system (CNS) stimulants [40].

\section{References}

1. I. A. Ajayi (2008). Comparative study of the chemical composition and mineral element content of Artocarpus heterophyllus and Treculia africana seeds and seed oils. Bioresources Technology, 99: 5125-5129.

2. S. A. Odoemelan (2005). Proximate Composition and selected physicochemical properties of the seeds of africa oil bean (Pentaclethra marcrophylla). Pakistan Journal of Nutrition, 4: 382-383
Terpenoids functions as phytoalexins [41]. A. paniculata seed oil terpenoids may find their usefulness in pharmacological activities such as anti-malaria, anti-ulcer etc. [42, 43]. Steroids have antibacterial properties and are important with their relationship with other compounds such as sex hormones [44]. Anthraquinones are largely applied in dye industry [45] as pesticide and additive in chemical alkaline pulp industry.

\section{CONCLUSION}

Afraegle paniculata seeds have good nutritional profile with high level of oil, protein, dietary fibre, minerals, and other nutrients comparable with that of other common legumes. The high percentage of $A$. paniculata seed oil affords its consideration as being economical for commercial production of vegetable oil in Nigeria. In the light of the explored nutritional facts, the oil has a potential of serving as a basis for the development of products in the cosmetics, pharmaceutical and food industries. The results also provide reference information for variety of Afraegle paniculata and other plants of Rutaceae family found in West Africa.

\section{ACKNOWLEGDEMENT}

The authors acknowledge the Department of Chemical Sciences, Faculty of Natural Sciences, Ajayi Crowther University, Oyo and Departments of Chemistry and Microbiology, Faculty of Science, University of Ibadan, Ibadan, Nigeria for their facilities.

3. R. F. Mohammed and M. J. Thomas (2003). "Determination of the lipid classes and fatty acid profile of Niger seed (Guizotia abyssinica Cass). Phytochem”. Analysis, 14: 366-370.

4. W. Caggiula and V. A. Mustad (1997). Effects of dietary fat and fatty acids on coronary artery disease risk and total and lipoprotein cholesterol concentrations: Epidemiologic studies. 
American Journal of Clinical. Nutrition, 65:1597S-1610S.

5. A. Keys (1970). Coronary heart disease in seven countries. American Heart Association Monograph Number 29. American Heart Association, New York.

6. S. Yu, J. Derr, T. D. Etherton and P. M. Kris (1995). Plasma cholesterol predictive equations demonstrate that stearic acid is neutral and monounsaturated fatty acids are hypocholesterolemic. American Journal of Clinical Nutrition, 61(5), 129-1139.

7. N. H. Baba, K. Antoniades and Z. Habbal (1998). Effects of dietary canola, olive, and linolenic acid enriched olive oils on plasma lipids, lipid peroxidation, and lipoprotein lipase activity in rats. Nutrition Research, 49: 41-45.

8. S. Bamba, A. M., Janat, V. David, R. M. K. Guy, P. Jean-Luc, and B. YvesAlain (2015). Analysis of a rutaceae fat matter from Côte d'Ivoire. Der Chemica Sinica, 6(4): 47-50

9. A. Asase, A. A. Oteng-Yeboah, G. T. Odamtten, and M. S. J. Simmonds (2005). Ethnobotanical study of some Ghanaian anti-malarial plants. Ethnopharmacology, 99: 273-279.

10. O. G. Ogaji, T. A. Tor-Anyiin, and N. P. Igoli (2005). Traditional medicine practice amongst the Igede people of Nigeria. African Journal Tradition Complementary and Alternative Medicine, 2: 134-152.

11. I. A. Ajayi, V. N. Aghanu, T. B. Adenuga (2013). Chemical analysis and toxicological assessment of defatted Greenwayodendron Suave lens seeds in rat feed. Journal of Environmental Toxicology and Food Technology, 4: 10-16.
12. S. A. Otitologbon, S. J. Oniye O. A. Peters and E. B Agbaji (1997). Proximate and mineral composition of three Nigerian fresh water fishes. Journal of Science of Food and Agriculture, 75: 312-314.

13. O. Olaofe, A. O. Ekuagbere and L. Ogunlade (2009). Chemical, amino acid composition and functional properties of calabash seed's kernel. Bulletin of Pure and Applied Siences, 28: $13-24$.

14. S. Guner, B. Dincer, N. Alemdag, A. Colak and M. Tufekci (1998). Proximate composition and selected mineral content of commercially important fish species from the Black Sea. Journal of Science, Food and Agriculture, 78: 337-342.

15. H. Umran, O. Canan, C. Sermin, O. Ali and E. Serap (2012). Major-minor element analysis in some plant seeds consumed as feed in Turkey. Natural Science, 4: 298.

16. A. Sofowora (1993). Medicinal plants and traditional medicine in Africa. Spectrum Books, Ibadan, pp: 150.

17. C. U. Solomon, U. Arukwe, I. Onocha (2013). Preliminary phytochemical screening of different solvent extraxts of stem bark and roots of Dennetia tripetala G. Baker. Asian Journal of Plant Science and Research, 3: 10-13.

18. G. A. Ayoola, H. A. Coker, S. A. Adesegun, A. A. Adepoju-Bello and K. Obayewa et al. (2008). Phytochemical screening and antioxidant activities of some selected medicinal plants used for malaria therapy in Southwestern Nigeria. Tropical Journal Pharmaceutical Research, 7: 1019-24.

19. B. Obdoni and P. Ochuko (2001). Phytochemical studies and comparative efficacy of the crude extracts of some homostatic plants in Edo and Delta States of Nigeria. 
Global Journal of Pure Applied Sciences, 8: 203-208.

20. C. Indumathi, G. Durgadevi, S. Nithyavani and P. K. Gayathr (2014). Estimation of terpenoid content and its antimicrobial property in Enicostemma litorrale. International Journal of Chemical Technology Research, 6: 4264 - 4267.

21. AOAC. (1999). Official Methods of Analysis. 21st Edn., Association of Official Analytical Chemists (AOAC), Washington, DC., USA.

22. M. M. Saad (2015). Effects of particle size and packing density on the yield of essential oil from lemon grass. B. Eng. Thesis. Ahmadu Bello University, Zaria.

23. E. Enas, A. A. Ahmed, A. A. Amal, M. A. and M. A. Manal (2018). Studies on Anaerobic bacteria in some cheese sold in Assiut city, Egypt. Journal of Advanced Veterinary Research, 8: 84-89.

24. Lakht-e-Zehra, Asadullah, G. Nabeela Dar, Nida Saleem, Umed Ali Soomro, Waqas Afzal, Beena Naqvi and Khalid Jamil (2015). Nutritional exploration of leaves, seed and fruit of bael (Aegle marmelos L.) grown in Karachi region. Pakistan Journal of Biochemistry and Molecular Biology, 48(3): 61-65.

25. U. Singh, A. Kochhar and R. Boora (2012). Proximate composition, available carbohydrates, dietary fibres and anti-nutritional factors in BAEL (Aegle marmelos) leaf, pulp and seed powder. International Journal of Scientific and Research Publications, 2 (4): 1-4

26. A. A. Taiwo, M. O. Agbotoba, J. A. Oyedepo, O. A. Shobo1, I. Oluwadare and M. O. Olawunmi (2008). Effects of drying methods on properties of water melon (Citrullus lanatus) seed oil. African Journal of Food
Agriculture, Nutrition and Development, 8: 4.

27. J. Hussain, A. L. Khan, N. Rehman, K. F. Zainullah, S. T. Hussain, Z. K. and Shinwari (2009). Proximate and nutrient investigations of selected medicinal plant species of Pakistan. Pakistan Journal of Nutrition, 8: 620624.

28. K. O. Esuoso and E. Bayer (1998). Chemical composition and potentials of some underutilized tropical biomass II Adenopus breviflorus and Cucumeropsis edulis. La Rivista Italiana Delle Sostanze Grasses, 75: 191-195.

29. R. E. Ogbemudia, B. C. Nnadozie, B. and Anuge (2017). Mineral and proximate composition of soy bean. Asian Journal of Physical and Chemical Sciences, 4(3): 1-6.

30. S. Bamba, G. R. M Kabran, J. A. Mamyrbékova-Békro, D. Virieux, J. L. Pirat and Y. A. Békro (2016). Chemical survey of Afraegle paniculata fruit seeds from Côte d'Ivoire. Asian Journal of Plant Science and Research, 6: 35-40.

31. A. Rathinam, M. Venkatachalam and B. Kanagasabai (2017). Highly clean and efficient enzymatic dehairing in green solvents. Journal of Cleaner Production, 140: 1578-1586.

32. S. Kittiphoom (2012). Utilization of mango seed. International Food Research Journal (Malaysia), 19: 1325-1335.

33. I. A. Ajayi, R. A. Oderinde, D. O. Kajogbola and J. I. Uponi, (2006). Oil content and fatty acid composition of some underutilized legumes from Nigeria. Food Chemistry, 99: 115-120.

34. J. L. R. Pritchard (1991). "Analysis and properties of oilseeds", in Analysis of oil seeds, fats and fatty foods, J. B. Rossell, and J. L. R. 
Pritchard, Eds. New York: Elsevier Applied Science, pp 80-98.

35. Codex Alimentarius Commission (1999). Codex Stan 19. Edible fats and oils not covered by individual standards. Retrieved January 30, 2020:

36. M. A. Lacaille-dubois and H. Wagner (2000). Bioactive saponins from plants: An update. In: Studies in Natural Products Chemistry; Atta-UrRahman, ed. Elsevier Science, 21: 633 $-687$.

37. C. O. Eleazu, P. N. Okafor and I. Ahamefuna (2010). Total antioxidant capacity, nutritional composition and inhibitory activity of unripe plantain (Musa paradisiacae) on oxidative stress in alloxan induced diabetic rabbits. Pakistan Journal of Nutrition, 9: 10521057.

38. O. A. Sodipo, J. A Akiniyi and J. U. Ogunbamosu (2000). Studies on certain characteristics of extracts of bark of Pansinystalia macruceras (K schemp) pierre Exbeille. Global Journal of Pure Applied Science, 6: 83-87.

39. M. Wink (2008). Ecological roles of alkaloids. In: Fattorusso E, Taglialatela-Scafati O (Eds) Modern alkaloids: structure, isolation Weinheimsynthesis and biology. Wiley-Vch.
40. H. A. Madziga, S. Sanni and U. K. Sandabe (2010). Phytochemical and Elemental Analysis of Acalypha wilkesiana leaf. Journal of American Science, 6(11), 510-514.

41. D. Mccaskill and R. Croteau (1998). Some caveats for bioengineering terpenoid metabolism in plants. Trends in Biotechnology, 16: 349-355.

42. J. H. Langenheim, (1994). Higher plant terpenoids: A phytocentric overview of their ecological roles. Journal of Chemical Ecology, 20: 1223- 1280.

43. N. Dudareva, E. Pichersky and J. Gershenzon (2004). Biochemistry of plant volatiles. Plant Physiology, 135: 1893-1902.

44. M. A. Amin, S. S. Sawhney and M. M. S. Jassal (2013). Qualitative and quantitative analysis of phytochemicals of Taraxacum officinale. Journal of Pharmacy and Pharmacology, 2: 001-005.

45. V. Mohanlall, P. Steenkamp and B. Odhav (2011). Isolation and characterization of anthraquinone derivatives from Ceratotheca triloba (Bernh.) Hook. f. Journal of Medicinal Plants Research, 5: 3132-41. 